\title{
Characteristics of migration from Serbia to Slovakia (on the example of the municipality of Kovačica)*
}

\author{
S. Stojšin, M. Šljukić, D. Hlavča \\ University of Novi Sad \\ Dr Zorana Đinđića St., 2, Novi Sad, Serbia \\ (e-mail: snezanas@ff.uns.ac.rs; marica.sljukic@ff.uns.ac.rs; danielahlavca@gmail.com)
}

\begin{abstract}
Due to numerous transformation problems which determined the collapse of the industrial sector, unemployment and low living standards, an increasing number of working population leaves Serbia. For a very long time, Serbian emigration was directed primarily to the developed Western European countries (especially Germany and Austria). However, Slovakia has recently joined the narrow circle of countries-destinations for emigrants from Serbia. The article focuses on this wave of the working population emigration from Serbia to Slovakia and considers it in the framework of the contemporary migration theories, especially the push-and-pull factors theory. The research data was compared with the relevant data from previous studies. The research was conducted in the municipality of Kovačica (northern Serbia) with a questionnaire on the sample of 100 respondents (the 'snowball' method was applied), and the authors also used various other data sources: statistical data (censuses, migration statistics, etc.), media reports and scientific papers. Given the unfavorable social-economic context of the Serbian working population emigration and the chosen theoretical framework, the authors considered economic factors as crucial for this wave of migration, which seems to be similar to the previous waves of migration. In general, this assumption was confirmed: emigrants from Serbia go to Slovakia for a variety of reasons, but the key ones are the small salary in Serbia, the impossibility to find a job in one's profession, and a poor financial and political situation in the country. On the other hand, Slovakia attracts Serbian migrants by offering possibilities to earn more money, to have higher living standards, better conditions for education and work, thus, promising a better and predictable future.
\end{abstract}

Key words: migration; factors of emigration; transformation of the Serbian society; working conditions; living standards; Serbia; Kovačica; Slovakia

The necessity to study international migratory routes is determined by the increasing mobility of workforce and by the importance of migrations for globalization. Traditionally, Serbia is an emigration area: from 2011 to 2016, its population decreased on average by 36,000 annually [17. P. 35]. In addition to the negative natural increase, this population decline was influenced to a great extent by migration [11]. Since monitoring of migrations is mainly based on the insufficient official data of receiving countries, it is hard to estimate the real number of migrants. According to some estimates, from 2002 to 2011, about 13,000 to

* (C) S. Stojšin, M. Šljukić, D. Hlavča, 2021

The article was submitted on 12.07.2021. The article was accepted on 28.09.2021. 
15,000 people left Serbia annually [9. P. 193]. In the earlier waves of emigration, the most popular countries were Austria and Germany (the number of Serbian emigrants in Austria changed from 1971 to 2011 from 19.7\% of the total number of emigrants from Serbia to $22.5 \%$; the same share of Serbian emigrants to Germany decreased from $45.8 \%$ to $17.9 \%$; while the share of Serbian emigrants to 'other European countries', including Slovakia, increased from $2.5 \%$ to $16.8 \%$ [19]), in recent years, the emigration to Slovakia for temporary work has increased.

We consider this new wave of emigration in the framework of the contemporary migration theories, especially the theory of push-and-pull factors [13. P. 211], which emphasizes the balance between negative push factors of the country of origin and the positive pull factors of the receiving country. D. Bogue describes different push factors (decrease of wealth, loss of jobs, oppressive or repressive policies, religion, ethnic origin, alienation from the community and a lack of possibilities to have a family) and pull factors (greater possibilities of employment and income, better opportunities for education, good living conditions and climate, dependence on the partner who emigrated, and new, different people and social environment) [2. P. 754]. However, in Serbia, economic factors of emigration seem to be dominant, which is the starting assumption of our research: for more than a quarter of a century, the Serbian society has been going through economic and social transformations characterized by strategic inconsistency, collapse of industry, rise of unemployment and, generally speaking, uncertainty. The assumption that economic factors are the main ones for emigration from Serbia to Slovakia (and the EU in general) is based on previous research and theoretical discussions $[1 ; 7 ; 8]$. To understand emigration processes in Serbia, push factors such as high unemployment, low standard of living and unfavorable conditions for development should be considered [1].

Many young people in Serbia think about emigration, and this trend emerged "one decade after the unblocked post-socialist transformation" [8. P. 229]: although young people are the most educated group in Serbia, they are losing confidence that they will be the winners of transformation. Already in 2004, the study [7] showed a great disappointment of young people in transformations which the youth defined as insignificant changes typical for the period after 2000. Young people showed a great desire for emigration, first, due to the unemployment, especially in their profession, then due to a very low income which did not provide a decent living and the possibility to buy a flat, and finally due to the impossibility to start a family [10]. Therefore, the results of the research in 2013 [8] are no surprise: a half of respondents (54\%) thought about leaving Serbia [8. P. 236], especially unemployed and young people without children [8. P. 241].

A particularly interesting issue is the selectivity of migration [1], especially the age of migrants as affecting the decision to migrate, since the majority of migrants are from 20 to 40 years old. Young people are more prepared for emigration because of the possible better position in the work market of the receiving country, their growing dissatisfaction in the country of origin, and a greater profitability of investing in migration [8. P. 233]. 
Although Slovakia is not traditionally a final destination for immigrants, in the last decade there has been an increasing number of immigrants: the immigrant population in Slovakia had the second largest rise in the EU countries - from 22,108 in 2004 to 97,934 in 2017 [3]. In June 2017, of the total number of immigrants from 130 countries the largest number came from Serbia $(8,808)$, followed by Romania $(8,621)$ [3].

Daily experience as well as theory (primarily theories of neoclassical economy, of the new economy of migrations, of dual or segmented labor market, of the world system, of social capital and of cumulative causality [4; 12]; we focus on neoclassical economic theories and the new economy of migrations) indicate that the main reasons for departure, i.e. migration, are economic. According to the theory of the world system [12], migration is a political-economic consequence of social transformations - when the existing relations are shaken by the emergence of a market, and the population uses migration to find new ways for survival [12. P. 336]. As a rule, migrants come not from poor and undeveloped regions, but rather from societies in transformation [12].

Our choice of the research topic was influenced by two factors. Frist, in the municipality of Kovačica in the Serbian province of Vojvodina, there is a large number of working populations who have either gone to Slovakia to work there temporarily or plan to leave. We also wondered if these were ethnic migrations, since Kovačica is the municipality with the largest number of Slovaks in Serbia, or they are the 'usual' economic migrations. The municipality of Kovačica is located in the South Banat County of the Autonomous Province of Vojvodina. Of 50,321 Slovaks who live in Vojvodina, every fifth Slovak in Serbia lives in the municipality of Kovačica: of the total number of 25,274 inhabitants, according to the last census, the majority are Slovaks $(10,577)$, followed by Serbs $(8,407)$ and Hungarians $(2,522)[14]$. The second reason for choosing this research question were numerous publications in the Serbian media about as if poor and inhumane working conditions in Slovakia. However, in our informal interviews with the inhabitants of this municipality who worked in Slovakia, most of them assured us that they were happy with their jobs in Slovakia and with the conditions of emigration.

Thus, our study aimed at identifying the reasons why many young people went to work in Slovakia and whether emigrants were happy with their jobs and working conditions. We used a variety of sources: statistical data (censuses and migration statistics), newspaper articles, scientific papers, but mainly the survey based on the questionnaire with 21 questions divided into three parts. The first part focused on the general information about respondents (gender, age and education), the second part - on the living conditions of respondents in Serbia and reasons for leaving, and the third part - on the satisfaction with work and working conditions in Slovakia. The 'snowball' sampling method was used, and a total of 100 respondents from the municipality of Kovačica in Serbia, who had (or still have) a working experience in Slovakia, were questioned: 53\% — men, $47 \%$ — women (this gender structure reflects the gender structure of emigrants from Serbia [19. P. 65]; 95\% ethnic Slovaks, 5\% - Serbs; the average age of respondents is 29.3 and more than 
a half $(54 \%)$ are under the age of 30 (which confirmed our assumption that people from 20 to 40 years old are more likely to emigrate; the majority graduated from high school (72\%), 21\% - from college or university.

According to the last census, in the municipality of Kovačica, $27 \%$ of population live on wages, $16 \%$ - on pension, $5.1 \%$ — on income from real estate, and $43.5 \%$ are supported persons [15]. 7,166 inhabitants on the municipality are employed (28.3\% of the total population, or $33.6 \%$ of the population over the age of 15 ), mainly in agriculture (20.6\%), followed by $19.1 \%$ craftsmen, and $16.8 \%$ of the inhabitants having simple jobs (courier, cleaner, and so on), $12.5 \%$ are employed in services or shops, $9.2 \%$ are engineers, associates and technicians, $7.2 \%$ are professionals and artists, $4.7 \%$ - administrative workers, only $1.9 \%$ are managers and functionaries [16].

The largest number of the population are employed in agriculture and crafts, which raises the question about the living standard of the people working in these unprofitable fields. In the first part of the questionnaire, an emphasis was made on the living standard of respondents before their departure to Slovakia: $80 \%$ were employed, while $20 \%$ have never worked. However, of the total number of the employed respondents, $43 \%$ had only seasonal jobs and 19\% were employed temporarily. Furthermore, $2 \%$ had 'moonlighting' jobs (were not registered by the employer), and one informant had his own small business. Only $15 \%$ of respondents were permanently employed. Thus, $80 \%$ of the employed respondents did not have a secure job, and only $19 \%$ were employed in their profession.

The significant influence of the poor financial situation (due to having temporary and/or occasional job) on the decision to leave Serbia is indicated by the following data: $36.6 \%$ of respondents named the poor financial situation among the most significant factors, 33.3\% - low wages in Serbia (Table 1). One of the most significant pull factors, i.e. motives for going to Slovakia, was better living conditions (Table 2).

Table 1

Reasons for leaving Serbia

\begin{tabular}{|c|c|}
\hline Factors & $\%$ \\
\hline Low wages & 33.3 \\
\hline Impossibility to find a job in one's profession & 11.3 \\
\hline Poor financial situation & 36.3 \\
\hline Bad political situation & 17.2 \\
\hline Ethnic tension & 1.6 \\
\hline
\end{tabular}

Reasons for moving to Slovakia

\begin{tabular}{|c|c|}
\hline Factors & $\%$ \\
\hline Better salary & 28.9 \\
\hline Better living conditions & 53.5 \\
\hline Friends or relative going to Slovakia & 4.4 \\
\hline Partner going to Slovakia & 8.8 \\
\hline Education & 3.5 \\
\hline Better future for children & 0.8 \\
\hline
\end{tabular}


The results of the Likert scale application also indicate the factors of emigration from Serbia to Slovakia: $78 \%$ of respondents blame the quality of life in Serbia (Table 3).

Table 3

Likert scale: push and pull factors

\begin{tabular}{|c|c|c|c|c|c|}
\hline Statements & $\begin{array}{c}\text { completely } \\
\text { disagree }\end{array}$ & $\begin{array}{c}\text { rather } \\
\text { disagree }\end{array}$ & $\begin{array}{c}\text { neither } \\
\text { disagree } \\
\text { nor agree }\end{array}$ & $\begin{array}{c}\text { rather } \\
\text { agree }\end{array}$ & $\begin{array}{c}\text { completely } \\
\text { agree }\end{array}$ \\
\hline $\begin{array}{c}\text { If I stayed in Serbia I would have } \\
\text { to do a job which does not fulfill } \\
\text { my expectations }\end{array}$ & 7 & 12 & 20 & 26 & 35 \\
\hline Life in Serbia is very good & 49 & 29 & 14 & 4 & 12 \\
\hline $\begin{array}{c}\text { If I had a job, I would stay in } \\
\text { Serbia }\end{array}$ & 22 & 21 & 27 & 18 & 30 \\
\hline \begin{tabular}{c} 
I do not see my future in Serbia \\
\hline $\begin{array}{c}\text { Jobs in Serbia are found } \\
\text { through connections }\end{array}$
\end{tabular} & 13 & 14 & 25 & 18 & 52 \\
\hline $\begin{array}{c}\text { One can save up much more } \\
\text { in Slovakia than in Serbia }\end{array}$ & 5 & 7 & 15 & 25 & 44 \\
\hline $\begin{array}{c}\text { If one wants to find a job in } \\
\text { Serbia, one has to be a member } \\
\text { of a political party }\end{array}$ & 6 & 6 & 21 & 29 & 38 \\
\hline $\begin{array}{c}\text { Only those who have no } \\
\text { possibility } \\
\text { to leave stay in Serbia }\end{array}$ & 10 & 15 & 32 & 17 & 26 \\
\hline
\end{tabular}

Emigrants often consider migrations as short-term and want to return to Serbia as soon as they save up a certain sum of money, but some of them do not want to come back. When asked if they intended to stay in Slovakia permanently, 30\% answered positively. On the other hand, another 30\% intended to return to Serbia after some time, while $15 \%$ wanted to use Slovakia as some sort of 'spring board' to go to another country. A quarter of respondents (24\%) did not think about whether they would stay in Slovakia or return to Serbia when they were leaving for Slovakia.

Although emigrants have different education and were not satisfied with their jobs in Serbia, more than a half work at factories in Slovakia (52\%). A smaller number of emigrants from Serbia are employed in the service sector in Slovakia: $8 \%$ work at hotels, restaurants or cafes, $6 \%$ - at shops or supermarkets, $4 \%$ - at kindergartens or schools, others - in construction, repair shops, farms, and so on. It should be mentioned that some respondents work at embassies, clinics and airlines, but these jobs are reserved for the ethnic-Slovak immigrants.

After finding a job in Slovakia, $43 \%$ of respondents have not changed it, while more than a half $(57 \%)$ have already changed their workplace or plan to do that, $19 \%$ have changed a few jobs. In Serbia, only $19 \%$ of respondents had a job they were educated and trained for, while in Slovakia this number is higher $-31 \%$.

The length of stay in Slovakia differs: most respondents stayed in Slovakia for only a few months $(39 \%)$ - they represent immigrants who went to Slovakia 
during the wave of working emigration from Serbia with peaks in 2016 and 2017 (at that time, many agencies were employing foreign workers for Slovakia). $8 \%$ of respondents stayed in Slovakia for less than a month, 7\% - for more than five years, and $23 \%$ - from two to five years. The majority of Serbian emigrants in Slovakia work five days a week (66\%), $8 \%$ - six days a week, $4 \%$ - every day, $7 \%$ - four days a week, $3 \%$ - three days a week, and $2 \%$ — only one day a week. The majority work eight hours a day (47\%), and $14 \%$ - twelve hours or more (a half of them works at factories). 19\% of respondents often work overtime and are paid for this extra work; $58 \%$ sometimes work overtime (only $3 \%$ of them are not paid for that), and almost a quarter (23\%) does not work overtime at all. $71 \%$ can go on vacation whenever they want, while $22 \%$ - only when it is acceptable and convenient for their employer. More than a half of respondents receives a monthly salary (57\%), $40 \%$ are paid by the hour, and 3\% receive a daily wage. The majority of employers in Slovakia pay for health insurance (86\%) and in the pension fund $(82 \%)$. Health insurance is not provided to $9 \%$ of respondents, $8 \%$ do not have a pension fund, and other are not sure or do not know. These data bring us closer to reasons why the jobs in Slovakia attract citizens of Serbia and other neighboring countries.

Although the previous text does not make an impression that the working conditions for immigrants in Slovakia are quite good, we asked respondents if they were satisfied with their jobs in Slovak companies, also to check the Serbian media reports on the poor working conditions of Serbian emigrants in Slovakia [5; 20]. For instance, according to one newspaper article, "every month, for miserly wages, thousands of people from Serbia come to Slovakia and work without a contract, as 'tourists' in rounds of three months. They work twelve hours a day for wages that are only a half of those set by the Slovakian law, and without a paid break" [5].

To explain the difference between our data and the information from the media obtained from interviews with emigrants, we reconsidered the structure of our sample: $95 \%$ of our respondents were Slovak (the survey was conducted in the municipality with the Slovak majority in its population), and we should take this fact into account when interpreting the data. Ethnic membership is a significant factor, because it facilitates the adaptation and integration of Slovak emigrants in the receiving country, helps them to find better jobs (in terms of both wages and working conditions), primarily due to the lack of the linguistic barrier and thanks to the similar cultural patterns. The assumption is that this category of immigrants in Slovakia is better accepted by employers, because there are no (or much less) difficulties in communication (linguistic and cultural).

Besides, in Slovakia, there are formal differences between immigrants from Serbia. Although ethnic Slovaks and other citizens of Serbia, who go to Slovakia to work, are foreign citizens, Slovak immigrants receive at their historical home the so-called krajanka - an ID card that allows them to work in Slovakia for five years, unlike other citizens of Serbia who come to Slovakia for three months, after which they have to go back home and stay there for another three months before they can return to Slovak factories. This advantage is one of the reasons why Slovaks from 
Serbia prefer to go and work in Slovakia rather than in some other country. To get citizenship, which is a precondition for a better paid job, the immigrant must stay in Slovakia for five years.

Other immigrants from Serbia, who do not belong to the Slovak ethnic group, prefer to go to Slovak towns to be employed at the industry. Most foreign workers are employed in the regions of Bratislava and Trnava, where large car factories and household appliance plants are located (mainly LG and Samsung factories). These are not Slovak but foreign companies which opened plants in Slovakia due to a number of advantages, and one of them is cheaper workforce. Perhaps, these factories started hiring immigrant workers from the neighboring countries, because the Slovak population demanded higher wages, but the companies preferred to import cheaper workforce from the neighboring countries with lower standards of living. The greatest demand in Slovakia is for industrial workers and seasonal agricultural workers (for the harvest period). Two buses of workers leave Vojvodina every week to Slovakia and the most demanded are "workers for the food, car and electric industries, for factories producing parts for LCD TVS and sandwich packing. Jobs are mainly manual and are learnt quickly, so anyone can do them" [6] after a short training which is possible even without a perfect knowledge of language. After the collapse of industry in Serbia (a great number of industrial workers lost their jobs), Serbian immigrants are directed to the Slovak industrial sector, because they can do such work due to having good knowledge and skills acquired in the process of formal education and at the factories in Serbia.

The migration we study is motivated mainly by the fact that both industrial and non-industrial organizations have a developed technical division of labor, which does not require too much efforts to adapt to the new work place. Simple actions that they have to learn and do determines an intensive mobility of the workforce, in which both migrant workers and employers are interested (cheaper workforce): the latter also do not worry about the quality of working conditions, because every worker who complains can be easily replaced by another worker who will be quickly trained to do what is needed.

Despite such a working climate, most respondents are not dissatisfied with their jobs in Slovakia, and the main indicators of job satisfaction are the regular income, possibilities of promotion, spending time with colleagues, and so on (Table 4).

Finally, we asked respondents about returning to Serbia: only $22 \%$ do not think about going back - 18\% named a better life in Slovakia as a reason to stay. More than a half of respondents would return to Serbia (56\%), and the reasons are various: they love Serbia (38\%), it does not make a difference where to work (11\%), a better life in Serbia (5\%), their family lives in Serbia (2\%).

Thus, due to transformation problems (the collapse of the industrial sector, unemployment, poor living standard, uncertainty, strategically inconsistent transition), an increasing number of the Serbian working population looks for employment abroad, and the attracting countries change: for a very long time, Serbian emigrants moved to Germany and Austria, followed by France and Scandinavian countries, but in the last three decades, there is an increasing 
emigration wave of the working population to distant continents (Asia, Australia, Canada), and to Slovakia. The advantage of Slovakia as compared to other countries is that it is a relatively close Slavic country, and in Serbia, there are many people who belong to the Slovak ethnic group (especially in the northern province of Vojvodina) and for whom this migratory route is the most favorable one. Emigrants from Serbia go to Slovakia for a variety of reasons: the main push factors are small wages, impossibility to find a job in one's profession, and a poor general financial and political situation; while the main pull factors are provided by Slovakia possibilities to earn more money, to have higher living standards, better conditions for education and, in general, a better future. However, although the standard of living in Slovakia is definitely better, because the economy is more developed than in Serbia, we should also take into account the influence of multinational (industrial) companies located in Slovakia - they are interested in labor immigrants, who accept even poor working conditions.

Table 4

Likert scale - job satisfaction

\begin{tabular}{|c|c|c|c|c|c|}
\hline Statements & $\begin{array}{l}\text { completely } \\
\text { disagree }\end{array}$ & $\begin{array}{c}\text { rather } \\
\text { disagree }\end{array}$ & $\begin{array}{c}\text { neither } \\
\text { disagree } \\
\text { nor agree }\end{array}$ & $\begin{array}{l}\text { rather } \\
\text { agree }\end{array}$ & $\begin{array}{l}\text { completely } \\
\text { agree }\end{array}$ \\
\hline $\begin{array}{c}\text { My salary is adequate } \\
\text { to the effort }\end{array}$ & 5 & 19 & 20 & 6 & 20 \\
\hline I never get my salary on time & 80 & 7 & 8 & 3 & 2 \\
\hline I get a bonus for a job well done & 14 & 13 & 17 & 4 & 32 \\
\hline $\begin{array}{l}\text { Mistakes at work are strictly } \\
\text { punished }\end{array}$ & 26 & 28 & 22 & 5 & 9 \\
\hline My job physically exhausts me & 31 & 21 & 19 & 1 & 8 \\
\hline My job gives me pleasure & 6 & 15 & 32 & 4 & 23 \\
\hline $\begin{array}{l}\text { I often force myself to go } \\
\text { to work }\end{array}$ & 34 & 28 & 24 & 0 & 4 \\
\hline $\begin{array}{l}\text { Working conditions have } \\
\text { a bad effect on my health }\end{array}$ & 39 & 24 & 24 & 0 & 3 \\
\hline A break at work is not paid & 21 & 11 & 14 & 1 & 43 \\
\hline $\begin{array}{l}\text { If I do my job well, I have the } \\
\text { possibility to get a promotion } \\
\text { and a better position }\end{array}$ & 7 & 10 & 22 & 2 & 39 \\
\hline I often think about quitting & 49 & 18 & 25 & 5 & 3 \\
\hline The job that I do is interesting & 4 & 11 & 28 & 22 & 35 \\
\hline I am afraid of being fired & 67 & 14 & 13 & 2 & 4 \\
\hline $\begin{array}{l}\text { I spend time with my colleagues } \\
\text { after work }\end{array}$ & 12 & 14 & 21 & 9 & 24 \\
\hline $\begin{array}{c}\text { I am satisfied with the expertise } \\
\text { of supervisor }\end{array}$ & 7 & 8 & 26 & 1 & 28 \\
\hline My supervisor is too demanding & 24 & 27 & 28 & 1 & 10 \\
\hline $\begin{array}{c}\text { My supervisor accepts my } \\
\text { suggestions }\end{array}$ & 3 & 14 & 21 & 0 & 22 \\
\hline
\end{tabular}




\section{References}

[1] Bobić M., Babović M. Međunarodne migracije u Srbiji — stanje i perspektive. Sociologija. 2013; LV (2). (In Serbian).

[2] Bogue D. Principles of Demography. New York; 1969.

[3] IOM: Migration in Slovakia. URL: https://www.iom.sk/en/migration/migration-in-slovakia.html.

[4] King R. Theories and Typologies of Migration: An Overview and A Primer. Malmö; 2012.

[5] Krsnik D. Reporter Nedeljnika na tajnom zadatku: Tri meseca u slovačkoj fabrici u kojoj se građani Srbije tretiraju kao robovi. URL: http://admin.nedeljnik.rs/nedeljnik/portalnews/ reporter-nedeljnika-na-tajnom-zadatku-tri-meseca-u-slovackoj-fabrici-u-kojoj-se-gradanisrbije-tretiraju-kao-robovi. (In Serbian).

[6] Matijević J, Rogač M. Da nema ljudi iz Srbije stale bi fabrike. URL: http://www.novosti.rs/ vesti/naslovna/drustvo/aktuelno.290.html:645703-Da-nema-Srba-stale-bi-trake-u-fabrikama. (In Serbian).

[7] Mihailović S. Oduzimanje budućnosti: Omladina Srbije u vodama tranzicije. Mihailović S. (Ed.). Mladi izgubljeni u tranziciji. Beograd; 2004. (In Serbian).

[8] Mojić D., Petrović I. Mladi i legitimnost društvenog poretka u Srbiji: razmišljanja i delanja u pravcu emigracije. Sociologija. 2013; LV (2). (In Serbian).

[9] Nikitović V. Migraciona tranzicija u Srbiji: Demografska perspektiva. Sociologija. 2013; LV (2). (In Serbian)

[10] Nikolić M. Uvod: mladi su budućnost ovog društva. Mihailović S. (Ed.). Mladi izgubljeni u tranziciji. Beograd; 2004. (In Serbian).

[11] Penev G., Predojević-Despić J. Promene Stanovništva Srbije u postjugoslovenskom periodu (1991-2017): Važniji demografski aspekti. Sociološki Pregled. 2019; LIII (3). (In Serbian).

[12] Poleti D. Savremene radne migracije u evropskom kontekstu — ekonomski i politički aspekti. Sociologija. 2013; LV (2). (In Serbian).

[13] Predojević-Despić J. Migrantske mreže: nezaobilazna perspektiva u proučavanju savremenih međunarodnih migracija. Sociološki Pregled. 2009; XLIII (2). (In Serbian).

[14] SORS. Religion, mother tongue and ethnicity. 2011 Census of Population. Households and Dwellings in the Republic of Serbia. Book 4. Belgrade; 2013.

[15] SORS. Sources of Livelihood. 2011 Census of Population. Households and Dwellings in the Republic of Serbia. Belgrade; 2014.

[16] SORS. Economically active population that perform occupation. 2011 Census of Population. Households and Dwellings in the Republic of Serbia. Book 19. Belgrade; 2014.

[17] SORS. Statistical Yearbook of the Republic of Serbia. Belgrade; 2017.

[18] SORS. Workforce survey. November 30, 2017. Belgrade; 2017. (In Serbian).

[19] Stanković V. Srbija u procesu spoljnih migracija. Beograd; 2014. (In Serbian).

[20] Veselinović T. Privremeni rad u Slovačkoj: Ponižavajući uslovi, bez ugovora. URL: https://rs.n1 info.com/biznis/a228439-ponizavajuci-uslovi-za-radnike-u-slovackoj. (In Serbian).

DOI: $10.22363 / 2313-2272-2021-21-4-881-890$

\section{Особенности миграции из Сербии в Словакию (на примере муниципалитета Ковачица)*}

\section{С. Стойшин, М. Шлюкич, Д. Хлавча}

Университет Нови Сада

ул. Др. Зорана Джинджича, 2, Нови Сад, Сербия

(e-mail: snezanas@ff.uns.ac.rs; marica.sljukic@ff.uns.ac.rs; danielahlavca@gmail.com)

Аннотация. Следствием многочисленных трансформационных проблем в Сербии (разрушение промышленного сектора, безработица и низкий уровень жизни) стал возрастающий

* (C) Стойшин С., Шлюкич М., Хлавча Д., 2021

Статья поступила 12.07.2021 г. Статья принята к публикащии 28.09.2021 2. 
миграционный отток трудоспособного населения. В течение длительного времени сербские трудовые мигранты устремлялись преимущественно в развитые страны Западной Европы (особенно Германию и Австрию). Однако в последние годы Словакия пополнила достаточно узкий круг стран, куда направлена сербская трудовая миграция. Статья посвящена этой новой волне миграционного оттока трудоспособного населения из Сербии в Словакию, и авторы рассматривают ее в контексте современных миграционных теорий, особенно теории факторов притяжения и выталкивания. Полученные опросные данные были сопоставлены с результатами предшествующих проектов. Анкетирование было проведено на севере Сербии, в муниципалитете Ковачица на выборке в 100 человек, отобранных методом «снежного кома» (по критерию участия в миграции в Словакию), и авторы также использовали статистические данные (переписи, миграционная статистика и т.д.), сообщения средств массовой информации и научные работы. Учитывая неблагоприятную социальноэкономическую ситуацию в Сербии, определяющую масштабы и векторы трудовой эмиграции, и выбранный ими концептуальный подход, авторы считают экономические причины главным фактором нынешней волны сербской трудовой миграции, что делает ее похожей на все предыдущие волны. В целом это предположение было подтверждено результатами эмпирического исследования: мигранты из Сербии едут в Словакию по многим причинам, но все же основные - это низкие зарплаты, невозможность найти работу по профессии и сложная финансовая и политическая ситуация в стране. С другой стороны, Словакия привлекает сербских мигрантов, предлагая им возможности более высокого заработка, более высокого уровня жизни, лучших условий получения образования и работы, т.е., по сути, гарантируя им лучшее и предсказуемое будущее.

Ключевые слова: миграция; факторы эмиграции; трансформация сербского общества; условия работы; уровень жизни; Сербия; Ковачица; Словакия 